\title{
Phytotoxic property of seed methanolic extracts from Albizia (Fabaceae) endemic species of Madagascar
}

\author{
Hanitra Ranjana Randrianarivo ${ }^{1}$, Holy Christiane Ratsimanohatra ${ }^{2}$, \\ Anjarasoa Ravo Razafndrakoto ${ }^{2}$, Clara Fredeline Rajemiarimoelisoa ${ }^{3}$, \\ Lovarintsoa Judicael Randriamampianina ${ }^{2}$, Lolona Ramamonjisoa ${ }^{4}$, \\ Danielle Aurore Doll Rakoto ${ }^{1}$, Victor Louis Jeannoda ${ }^{1}$ \\ ${ }^{1}$ Laboratory of Applied Biochemistry to Medical Sciences, Fundamental and Applied Biochemistry Department, Faculty of Sciences, \\ University of Antananarivo, PO Box. 906, Antananarivo 101, Madagascar \\ ${ }^{2}$ Graduate School of Life Sciences and Environment of the University of Antananarivo, PO Box. 906, Antananarivo 101, Madagascar \\ ${ }^{3}$ Department of Pharmacy, Faculty of Medicine, PO Box 375, Antananarivo 101, Madagascar \\ ${ }^{4}$ National Tree Seed Centre (SNGF), PO Box. 5091, Antananarivo 101, Madagascar
}

\section{Email address:}

ranjanamaso@yahoo.fr (H. R. Randrianarivo), ratsimanohatraholy@yahoo.fr (H. C. Ratsimanohatra), anjravo@yahoo.fr (A. R. Razafindrakoto), bouba_lova@yahoo.fr(L. J. Randriamampianina), lolona.sngf@moov.mg (L. Ramamonjisoa), fredeline_rajemi@yahoo.fr (C. F. Rajemiarimoelisoa), dad.rakoto@yahoo.fr (D. A. D. Rakoto), victor_jeannoda@yahoo.fr (V. L. Jeannoda)

\section{To cite this article:}

Hanitra Ranjana Randrianarivo, Holy Christiane Ratsimanohatra, Anjarasoa Ravo Razafndrakoto, Clara Fredeline Rajemiarimoelisoa, Lovarintsoa Judicael Randriamampianina, Lolona Ramamonjisoa, Danielle Aurore Doll Rakoto, Victor Louis Jeannoda. Phytotoxic Property of Seed Methanolic Extracts from Albizia (Fabaceae) Endemic Species of Madagascar. Journal of Plant Sciences.

Vol. 2, No. 6, 2014, pp. 256-265. doi: 10.11648/j.jps.20140206.11

\begin{abstract}
Investigations on the phytotoxicity of Albizia species were conducted under laboratory conditions in order to assess their possible use in the control of weeds and invasive plants. The effects of seed methanolic extracts obtained from $A$. androyensis, A. bernieri, A. divaricata, A. greveana, A. masikororum and A. viridis, all endemic of Madagascar were evaluated against seed germination and early seedling development of vegetables (Phaseolus vulgaris, Pisum sativum, Petroselinum crispum, Brassica sp., Cucumis sp., Allium cepa, Zea maÿs and Oryza sativa). The effects of these extracts on seed germination of weeds (Eragrostis pilosa, and Panicum subalbidum) and invasive plants (Acacia dealbata, Cassia rotundifolia and Pinus kesyia $)$ were also studied. Globally, all the extracts $(1 \mathrm{mg} / \mathrm{mL})$ inhibited the seed germination of all the test plants. However, the inhibitory effect varied according to both the Albizia extract and the target plants. Inhibition rates could reach $100 \%$. The extracts $(0.45$ to $7 \mathrm{mg} / \mathrm{mL})$ also significantly $(\mathrm{p}<0.05)$ reduced the length of both epicotyl and hypocotyl and the effects were generally in a dose dependent manner. At the same concentration $(7.2 \mathrm{mg} / \mathrm{mL})$ with some extracts, the inhibitory effect was as high as glyphosate, a weed-killer widely used in agriculture. At low concentrations $(0.45-0.9 \mathrm{mg} / \mathrm{mL})$ a high stimulatory effect of up to $200 \%$ was observed with some extracts. Overall, the results obtained supported the probable involvement of seed secondary metabolites in the allelopathic interactions of Albizia species with other plants and could be exploitable in the control of undesirable plants.
\end{abstract}

Keywords: Albizia, Seed Methanolic Extract, Phytotoxic, Seed Germination, Seedling Growth, Weeds, Invasive Plants, Allelopathy, Herbicide

\section{Introduction}

In agriculture and forestry, the need to protect crops and to restrict the damaging effects of invasive plants led for about thirty years to the development of a number of broad-spectrum synthetic herbicides such paraquat and especially glyphosate and its derivatives $[1,2]$.
The use of these compounds had not only released millions of farmers from the duty of manual weeding but also permitted to develop sustainable and more productive new agriculture systems [3].

Even the efficiency of these pesticides in short term has been proved, their harmful effects in long term are far from to be not significant. Indeed, it was observed that the intensive 
use of herbicides resulted in flora impoverishment in regularly weeded parcels, weed resistance phenomenons appeared and the persistence of these compounds make worse the risks of water pollution and soil degradation [2, 4-6].

Facing these disadvantages, there is an urgent need to explore and utilize naturally occurring products for combating harmful agricultural and public health pests $[7,8]$.

Many plants are known to have herbicidal properties. Extracts from the fresh leaves of Tree of Heaven (Ailanthus altissima L.) (Simaroubaceae) showed a strong plant germination and growth inhibitory effect in laboratory bioassays against alfalfa (Medicago sativa) [7]. The allelopathic potential of aqueous leaf and root extracts of Aloe ferox Mill. was evaluated against seed germination and seedling growth of three vegetables turnip (Brassica rapa), beetroot (Beta vulgaris) and carrot (Daucus carota) [9].

The current study is a part of a wide program on toxic plants aiming to find compounds of interest such as pesticides molecules [10-13]. It is a continuation of the previous works on the toxic activity of the endemic species of Albizia of Madagascar on various organisms [13-17]. It was conducted in order to determine the effects of the seed methanolic extracts from six other species (A. bernieri, A. androyensis, $A$. divaricata, $A$. greveana, $A$. masikororum and $A$. viridis) on the germination of seeds and the early growth of seedlings. Our objectives were to verify if these Albizia seed extracts toxic on animals were also phytotoxic and to investigate how they might be used in the control of undesirable plants.

\section{Experimental}

\subsection{Plant Material}

Albizia species are trees or treelets or shrubs. About 145 species of these plants are widely distributed in tropical regions. In Madagascar, 30 Albizia species are present, 24 of which are endemic [18].

\subsubsection{Albizia Seeds}

Origin and collection sites of Albizia seeds and herbarium references of the corresponding plants were already reported in a previous paper [17].

Voucher specimen of each plant was deposited in the herbarium of SNGF and in that of Plant Biology and Ecology Department of the Faculty of Sciences of the University of Antananarivo.

\subsubsection{Vegetable Seeds}

Seeds of bean (Phaseolus vulgaris), pea (Pisum sativum), maize (Zea maÿs), rice (Oryza sativa), parsley (Petroselinum crispum), white tissam (Brassica sp), onion (Allium cepa) and cucumber (Cucumis sp.) were provided by the Ministry of Agriculture.

\subsubsection{Weed and Invasive Plant Seeds}

The seeds of 5 plants considered as weeds (Eragrostis pilosa, Panicum subalbidum and Cassia rotundifolia) and invasive plants (Acacia dealbata and Pinus kesyia) in
Madagascar and/or elsewhere [19-21] came from SNGF. The herbarium reference numbers of these plants are presented in table 1 .

Table 1. List and herbarium reference numbers of the studied weeds and invasive plants.

\begin{tabular}{ll}
\hline Plant & Herbarium reference number \\
\hline Eragrostis pilosa & MSB 3139 \\
Panicum subalbidum & MSB 3008 \\
Cassia rotundifolia & 13080 \\
Acacia dealbata & 12189 \\
Pinus kesyia & 13099 \\
\hline
\end{tabular}

\subsection{Seed Methanolic Extracts (SME) Preparation}

Seed methanolic extracts (SME) of each Albizia species used for tests were prepared as previously described [17].

\subsection{Assays on Seed Germination}

\subsubsection{Assays on Vegetable Seed Germination}

The seed surface was sterilized by soaking in sodium hypochlorite solution (5\%) for $1 \mathrm{~min}$. Treated seeds were washed immediately and thoroughly with distilled water.

For each plant test, one lot of 10 seeds was separately soaked in the different extracts during $48 \mathrm{~h}$ in the dark and another lot soaked in distilled water served as control. Seeds were then transferred on to Petri dish lined with cotton or blotting paper soaked with extracts (tests) or with distilled water (control). Each treatment had four replicates. Over a period of 15 days, substrate was moistened every two days with extract (test) or water (control) and germinated seeds were counted. Results were expressed as germination percentage.

\subsubsection{Assays on Weed and Invasive Plant Seed Germination}

Cassia rotundifolia and Acacia dealbata seeds needed pretreatment consisting in soaking in boiling water and the whole was allowed to cool down during $24 \mathrm{~h}$. That treatment was carried out because of the presence of inhibitors in the seed coats and the mechanical strength of seed coats against the embryo growth. The seeds of Eragrostis pilosa, Panicum subalbidum and Pinus kesyia were treated as the vegetable seeds.

Cassia rotundifolia, Acacia dealbata, Pinus kesyia seeds were allowed to germinate on sand substrate. Otherwise other experiment conditions were the same than described above for vegetable seed germination.

SME concentration used in all seed germination assays was $1 \mathrm{mg} / \mathrm{mL}$. According to preliminary results, this concentration was the lowest one which was efficient on most of seeds.

\subsection{Assays on Vegetable Seedling Development}

Bean, pea, maize and rice were chosen as test plants because their seeds are comparatively large, germinate quickly enough and above all their hypocotyls and epicotyls were easy enough to measure. 
Because the available seed amount was not sufficient $A$. masikororum was not studied and $A$. greveana was examined only on two test plants.

Seeds were soaked in water during $48 \mathrm{~h}$ at $30^{\circ} \mathrm{C}$ in the dark. Germinated seeds were transferred into Petri dishes lined with cotton or blotting paper soaked with water (control) or with extracts (tests) at increasing concentrations. Five concentrations $(0.45,0.9,1.8,3.6$ and $7.2 \mathrm{mg} / \mathrm{mL})$ were used except for A. divaricata SME on pea and maize where another range of weaker concentrations $(0.06,1 \mathrm{mg} / \mathrm{mL})$ was used since at concentrations higher than $1 \mathrm{mg} / \mathrm{mL}$ seedling growth was totally inhibited.

Glyphosate, a specific inhibitor of the shikimate pathway which is widely utilized in agriculture as a non-selective weed killer, was used as a negative control at the concentration of $7.2 \mathrm{mg} / \mathrm{mL}$ recommended by the producer.

Substrate was moistened with extract (test) or water (control) and length measurement of epicotyls and hypocotyls were carried out every 2 days during 13 days [15]. The inhibitory effects of extracts were expressed in terms of hypocotyl and epicotyl length reduction. The relative germination ratio (RGR) was calculated as in [22] (1) and the inhibition rate was obtained from it (2):

$$
\begin{gathered}
\mathrm{RGR}=\frac{\text { Germination ratio of test plant }}{\text { Germination ratio of control }} \times 100 \\
\text { Inhibition rate }(\%)=100 \%-\mathrm{RGR}
\end{gathered}
$$

One-way analysis of variance (ANOVA) which was followed by Newman Keuls comparison test with Staticf $®$ software was used for statistical analysis. Statistical estimates were made at confidence interval of $95 \%$.

\section{Results}

\subsection{Effects of Albizia SME on Vegetable Seed Germination}

When compared with a water control, most of Albizia SME exerted an inhibitory effect on the germination of vegetable seeds (table 2). Except for pea and white tissam seeds which could normally germinate in the presence of respectively $A$. androyensis and $A$. masikororum $\mathrm{SME}$ at $1 \mathrm{mg} / \mathrm{mL}$, all the other treated vegetable seeds were sensitive to the Albizia SME but with variable responses. In most cases, the extent of the inhibitory effect could get as high as $100 \%$. The lowest and the highest susceptibility were respectively observed on seeds of white tissam and onion where inhibition rates ranged between 0 and $30 \%$ for the former and 80 and $100 \%$ for the latter. Besides, the response of the test plants to the same extract treatment was different. As an example, $A$. viridis SME inhibited the germination of parsley, cucumber and onion by $100 \%$ but that of maize and rice only by 5 and $10 \%$ respectively.

It should be noted that some of non-germinating seeds decayed.

\section{Statistical Analysis}

Table 2. Effects of Albizia SME (1 $\mathrm{mg} / \mathrm{mL})$ on vegetable seed germination.

\begin{tabular}{llllllll}
\hline \multirow{2}{*}{ Vegetable } & \multicolumn{2}{l}{ Inhibition rate (\%) } & & & & \\
\cline { 2 - 7 } & DW & A. androyensis & A. bernieri & A. viridis & A. divaricata & A. greveana & A. masikororum \\
\hline Bean & 0 & 50 & 40 & 55 & 40 & 100 & 42.1 \\
Pea & 0 & 0 & 7.5 & 25 & 90 & 85 & 43.8 \\
Parsley & 0 & 70 & 100 & 100 & 90 & 60 & 90.9 \\
White tissam & 0 & 10 & 2.5 & 20 & 25 & 30 & 0 \\
Cucumber & 0 & 20 & 52.5 & 100 & 100 & 30 & 58.3 \\
Onion & 0 & 100 & 80 & 100 & 90 & 90 & 80 \\
Maize & 0 & 30 & 20 & 5 & 10 & 50 & 47.4 \\
Rice & 0 & 30 & 50 & 10 & 50 & 21.4 \\
\hline
\end{tabular}

DW: distilled water

\subsection{Effects of Albizia SME on Weed and Invasive Plant Seed Germination}

Inhibition rates of the invasive plant seed germination by the Albizia SME were shown in table 3.

All weed and invasive plant seeds were sensitive to all Albizia SME. Among the tested plants, Eragrostis pilosa seemed to be the most sensitive with inhibition rate ranged between $96.67 \%$ (with $A$. bernieri SME) and $100 \%$ (with $A$. greveana SME), and Pinus kesyia the least sensitive with inhibition rate ranged between $12.50 \%$ (with A. viridis SME) and $37.50 \%$ (with $A$. masikororum SME). Effect of the same
Albizia SME varied according to the test plants. As an example A. viridis SME inhibited the germination of Cassia rotundifolia by $100 \%$ and Acacia dealbata and Pinus kesyia by 40 and $12.50 \%$ respectively.

\subsection{Effects of Albizia SME on Vegetable Seedling Growth}

The effects of Albizia SME on the test plants growth monitored at the 13th day of experiment are presented in tables 4-9. Examples showing the evolution of hypocotyl and epicotyl elongation of the test plants every two days throughout the experiment are presented in fig. 1-6. 
Table 3. Effects of Albizia SME $(1 \mathrm{mg} / \mathrm{mL})$ on weed and invasive plant seed germination.

\begin{tabular}{llllll}
\hline \multirow{2}{*}{ Plant species } & \multicolumn{2}{l}{ Inhibition rate (\%) } & & & \\
\cline { 2 - 6 } & Distilled water & A. bernieri & A. greveana & A. masikororum & A.ridis \\
\hline Eragrostis pilosa & 0 & 96.67 & 100.00 & 99.71 & 98.57 \\
Panicum subalbidum & 0 & 73.33 & 86.79 & 81.47 & 66.79 \\
Cassia rotundifolia & 0 & 70.00 & 90.00 & 67.50 & 100.00 \\
Acacia dealbata & 0 & 35.00 & 30.00 & 15.00 & 40.00 \\
Pinus kesyia & 0 & 20.00 & 22.50 & 37.50 & 12.50 \\
\hline
\end{tabular}

Table 4. Inhibition rates (\%) of bean hypocotyl $(H)$ and epicotyl (E) elongation at the 13th day of treatment with the Albizia SME.

\begin{tabular}{ccllll}
\hline \multicolumn{2}{c}{ Albizia SME $(\mathbf{m g} / \mathbf{m L})$} & A. androyensis & A. bernieri & A. viridis & A. divaricata \\
\hline \multirow{2}{*}{0} & H & 0 & 0 & 0 & 0 \\
0.45 & E & 0 & 0 & 0 & 0 \\
& H & 41.8 & 11.4 & 32.3 & $-3.5^{*}$ \\
0.9 & E & 43.9 & 18.2 & $-7.7^{*}$ & $-173.5^{*}$ \\
& H & 52.6 & 19.8 & 13.7 & 68.5 \\
1.8 & E & 51.0 & 33.5 & $-14.1^{*}$ & 18.0 \\
& H & 58.5 & 11.9 & 24.9 & 80.1 \\
3.6 & E & 59.4 & 14.5 & $-9.0^{*}$ & 79.1 \\
& H & 70.5 & 52.2 & 30.4 & 95.7 \\
& E & 90.3 & 69.9 & 18.8 & 89.8 \\
\end{tabular}

* : a negative sign before a number indicates a stimulatory effect.

Table 5. Inhibition rates (\%) of maize hypocotyl (H) and epicotyl (E) elongation at the 13th day of treatment with the Albizia SME.

\begin{tabular}{|c|c|c|c|c|c|c|}
\hline \multicolumn{2}{|c|}{ Albizia SME $(\mathrm{mg} / \mathrm{mL})$} & \multirow{2}{*}{$\begin{array}{l}\text { A. androyensis } \\
0\end{array}$} & \multirow{2}{*}{$\begin{array}{l}\text { A. bernieri } \\
0\end{array}$} & \multirow{2}{*}{$\begin{array}{l}\text { A. viridis } \\
0\end{array}$} & \multirow{2}{*}{$\begin{array}{l}\text { A. divaricata } \\
0\end{array}$} & \multirow{2}{*}{$\begin{array}{l}\text { A. greveana } \\
0\end{array}$} \\
\hline & $\mathrm{H}$ & & & & & \\
\hline 0 & $\mathrm{E}$ & 0 & 0 & 0 & 0 & 0 \\
\hline \multirow{2}{*}{0.45} & $\mathrm{H}$ & 71.0 & $-12.1 *$ & $-206.9 *$ & $-204.3^{*}$ & 68,4 \\
\hline & $\mathrm{E}$ & 91.5 & 40.7 & 52.4 & 40.4 & 95,2 \\
\hline \multirow{2}{*}{0.9} & $\mathrm{H}$ & 80.3 & $-37.9^{*}$ & $-145.7^{*}$ & $-183.6^{*}$ & 89,9 \\
\hline & $\mathrm{E}$ & 97.3 & 25.1 & 68.0 & 29.4 & 92,2 \\
\hline \multirow{2}{*}{1.8} & $\mathrm{H}$ & 86.4 & $-37.1^{*}$ & $-69.8^{*}$ & 11.2 & 82,8 \\
\hline & $\mathrm{E}$ & 99.1 & 55.6 & 57.1 & 88.1 & 91,1 \\
\hline \multirow{2}{*}{3.6} & $\mathrm{H}$ & 94.5 & 58.6 & $-9.5^{*}$ & 56.0 & 91,4 \\
\hline & $\mathrm{E}$ & 99.1 & 89.2 & 86.0 & 92.6 & 97,8 \\
\hline \multirow{2}{*}{7.2} & $\mathrm{H}$ & 98.6 & 72.4 & 42.2 & 100.0 & 91,4 \\
\hline & $\mathrm{E}$ & 99.3 & 87.7 & 92.2 & 100.0 & 97,8 \\
\hline
\end{tabular}

* : a negative sign before a number indicates a stimulatory effect

Table 6. Inhibition rates (\%) of pea hypocotyl (H) and epicotyl (E) elongation at the 13th day of treatment with the Albizia SME.

\begin{tabular}{|c|c|c|c|c|c|}
\hline \multicolumn{2}{|c|}{ Albizia SME(mg/mL) } & \multirow{2}{*}{$\begin{array}{l}\text { A. androyensis } \\
0\end{array}$} & \multirow{2}{*}{$\begin{array}{l}\text { A. bernieri } \\
0\end{array}$} & \multirow{2}{*}{$\begin{array}{l}\text { A. viridis } \\
0\end{array}$} & \multirow{2}{*}{$\begin{array}{l}\text { A. greveana } \\
0\end{array}$} \\
\hline 0 & $\mathrm{H}$ & & & & \\
\hline 0 & $\mathrm{E}$ & 0 & 0 & 0 & 0 \\
\hline \multirow{2}{*}{0.45} & $\mathrm{H}$ & 91.8 & 72.2 & 55.1 & 85,4 \\
\hline & $\mathrm{E}$ & 74.6 & $-16.4^{*}$ & $-24.6^{*}$ & 76,7 \\
\hline \multirow{2}{*}{0.9} & $\mathrm{H}$ & 95.4 & 75.4 & 61.3 & 83,7 \\
\hline & $\mathrm{E}$ & 90.3 & $-16.8 *$ & 18.5 & 86,2 \\
\hline \multirow{2}{*}{1.8} & $\mathrm{H}$ & 96.6 & 79.5 & 59.0 & 84,6 \\
\hline & $\mathrm{E}$ & 81.7 & 53.3 & 4.9 & 84,9 \\
\hline \multirow{2}{*}{3.6} & $\mathrm{H}$ & 96.9 & 85.4 & 66.4 & 87,1 \\
\hline & $\mathrm{E}$ & 87.9 & 81.9 & 13.2 & 91,5 \\
\hline \multirow{2}{*}{7.2} & $\mathrm{H}$ & 97.3 & 87.7 & 68.7 & 89,0 \\
\hline & $\mathrm{E}$ & 93.7 & 83.5 & 6.5 & 95,7 \\
\hline
\end{tabular}

\footnotetext{
* : a negative sign before a number indicates a stimulatory effect
} 
Table 7. Inhibition rates (\%) of rice hypocotyl (H) and epicotyl (E) elongation at the 13th day of treatment with the Albizia SME.

\begin{tabular}{lllll}
\hline \multicolumn{2}{c}{ Albizia SME(mg/mL) } & A. androyensis & A. bernieri & A. viridis \\
\hline \multirow{2}{*}{0} & H & 0 & 0 & 0 \\
0.45 & E & 0 & 0 & 0 \\
& H & 37.3 & 88.5 & 55.1 \\
0.9 & E & 29.3 & $-16.4^{*}$ & 87.0 \\
& H & 46.3 & 90.2 & 58.2 \\
1.8 & E & 57.1 & $-16.8^{*}$ & 85.7 \\
& H & 51.0 & 91.3 & 77.4 \\
3.6 & E & 63.4 & 53.3 & 79.7 \\
& H & 58.0 & 88.0 & 68.3 \\
7.2 & E & 75.7 & 81.9 & 88.4 \\
& H & 82.7 & 91.5 & 76.7 \\
\hline
\end{tabular}

As compared to control, all the Albizia SME had an effect on all the test plants. However, the sensitive test plant(s) and the nature (stimulation and/or inhibition) and the extent of the effect were variable.

Table 8. Inhibition rates (\%) of rice and pea hypocotyl (H) and epicotyl (E) elongation at the 13th day of treatment with the A. divaricata SME.

\begin{tabular}{llll}
\hline A. divaricata SME $(\mathbf{m g} / \mathbf{m L})$ & & Pea & Rice \\
\hline \multirow{2}{*}{0} & H & 0 & 0 \\
& E & 0 & 0 \\
0.06 & H & 38.3 & 12.5 \\
& E & 3.7 & 58.6 \\
0.125 & H & 52.3 & 23.0 \\
0.5 & E & 24.7 & 64.3 \\
\hline
\end{tabular}

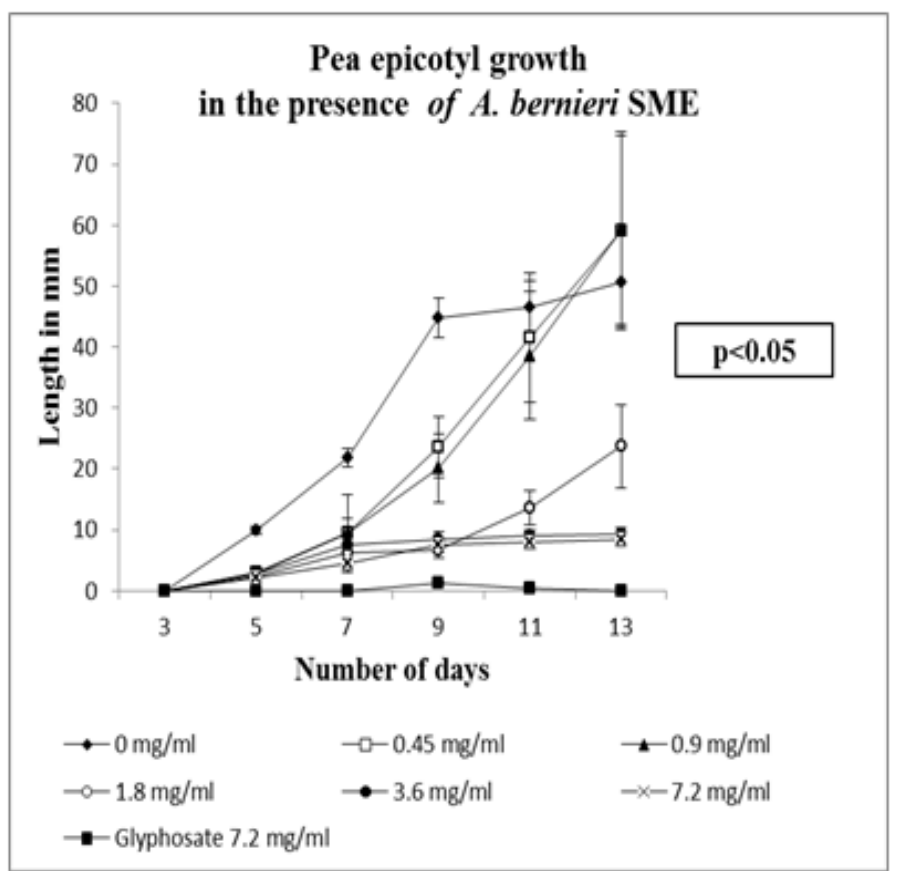

\begin{tabular}{llll}
\hline A. divaricata SME $(\mathbf{m g} / \mathbf{m L})$ & & Pea & Rice \\
\hline \multirow{4}{*}{1.25} & E & 58.6 & 60.0 \\
& H & 76.1 & 93.0 \\
1 & E & 74.8 & 74.3 \\
& H & 99.7 & 100.0 \\
& E & 74.8 & 81.6 \\
\hline
\end{tabular}

\subsubsection{Stimulatory Effects Albizia SME}

Except for A. androyensis and A. greveana SME the three other Albizia SME exhibited a stimulatory effect on some test plants. Stimulation was generally observed at low concentrations $(0.45$ and $0.9 \mathrm{mg} / \mathrm{mL})$ but in maize treated with A. viridis (table 6) it still demonstrated at $3.6 \mathrm{mg} / \mathrm{mL}$. In a same test plant stimulation concerned the elongation of either only hypocotyl (e.g. Maize treated with $A$ bernieri, A. divaricata and $A$. viridis) (table 6 and fig. 1) or only epicotyl (e.g. pea and rice treated with $A$. bernieri) (table 8 and fig. 1).

\subsubsection{Inhibitory Effects of Albizia SME}

Except for the stimulatory effect at low concentrations, significant inhibitory effect $(\mathrm{p}<0.05)$ was observed at the other concentrations. Globally, inhibitory potential significantly $(p<0.05)$ increased with increasing concentrations of Albizia SME (fig. 2, 3, 5). However, the extent of the inhibitory effect varied according to both Albizia SME and test plant (tables 5-8 and fig. 2-6). For example, on pea hypocotyl growth inhibition rates varied between 55.1 and $68.7 \%$ when treated with $A$ viridis SME and between 91.8 and $97.3 \%$ when treated with $A$ androyensis SME (table 6); on hypocotyl growth treated with A. bernieri SME inhibition rates varied between 11.4 and $56.5 \%$ in bean (table 5) and 88.5 and $91.5 \%$ in rice (table 7).

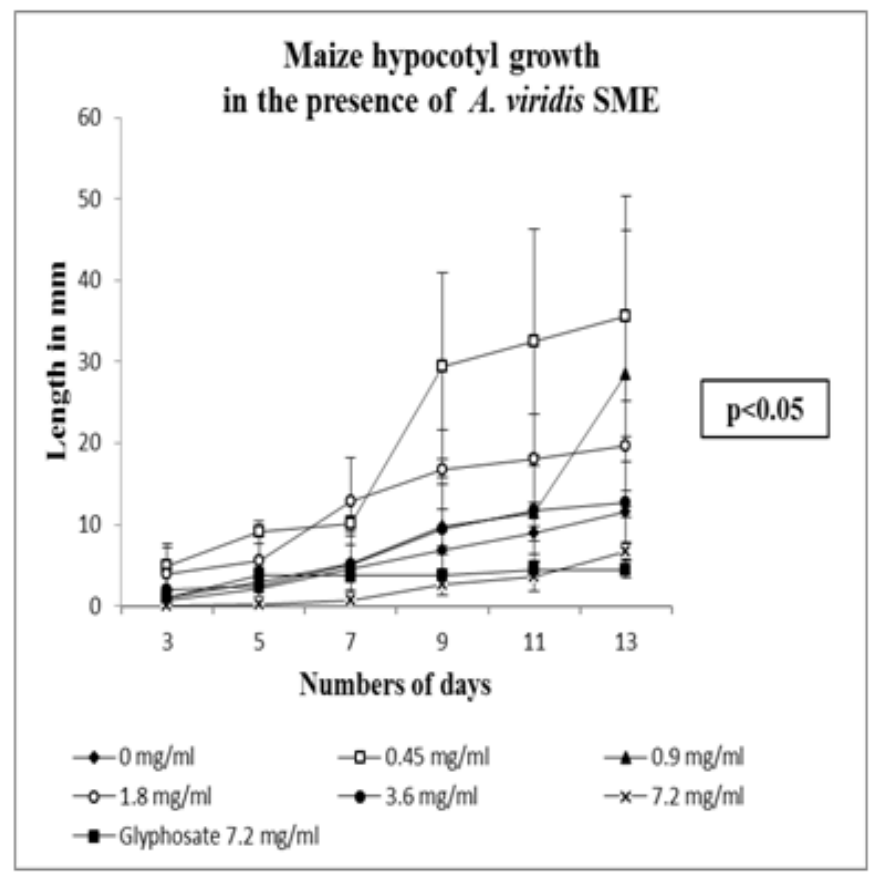

Fig. 1. Stimulatory effects of Albizia SME on hypocotyl and epicotyl of test plants. 

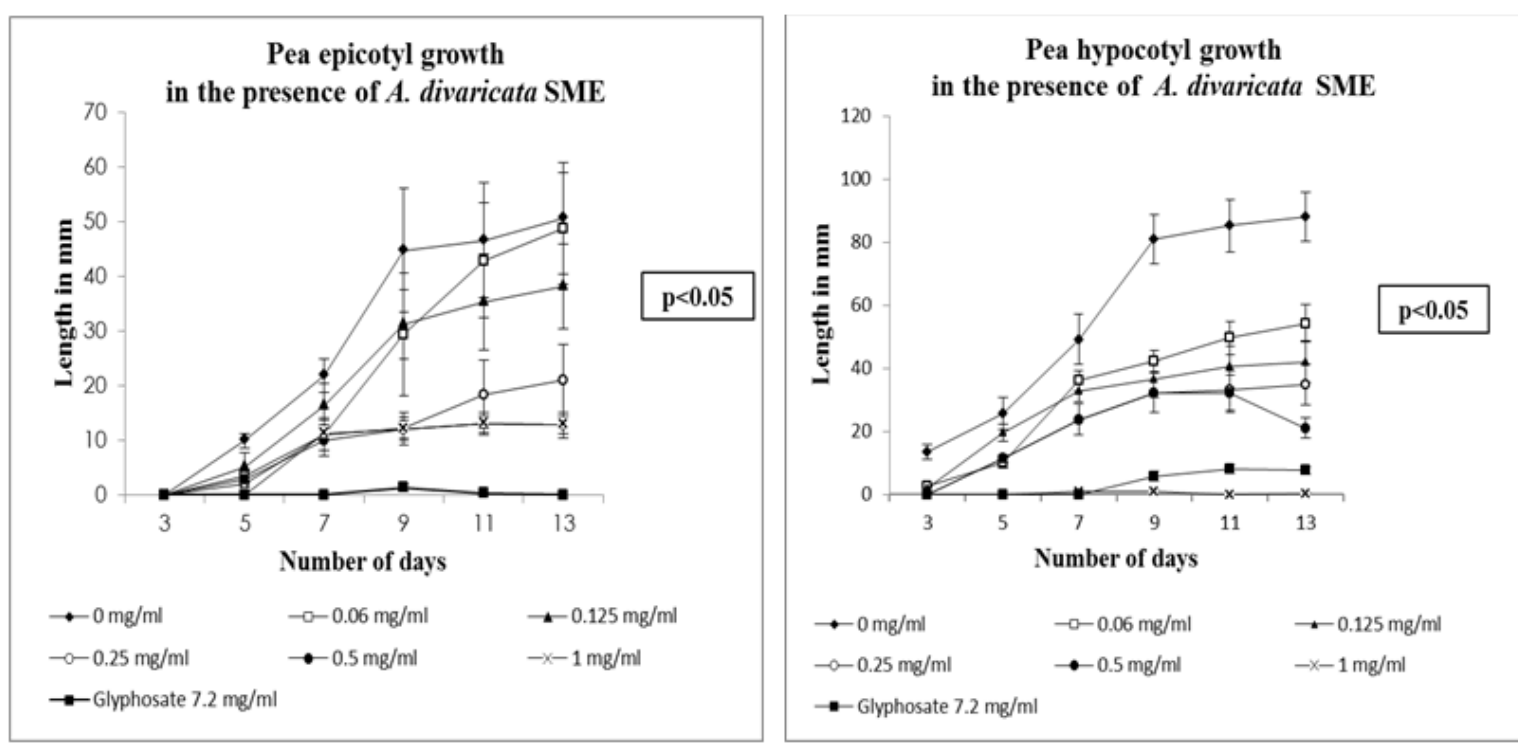

Fig. 2. Effects of A. divaricata SME on pea seedling growth.
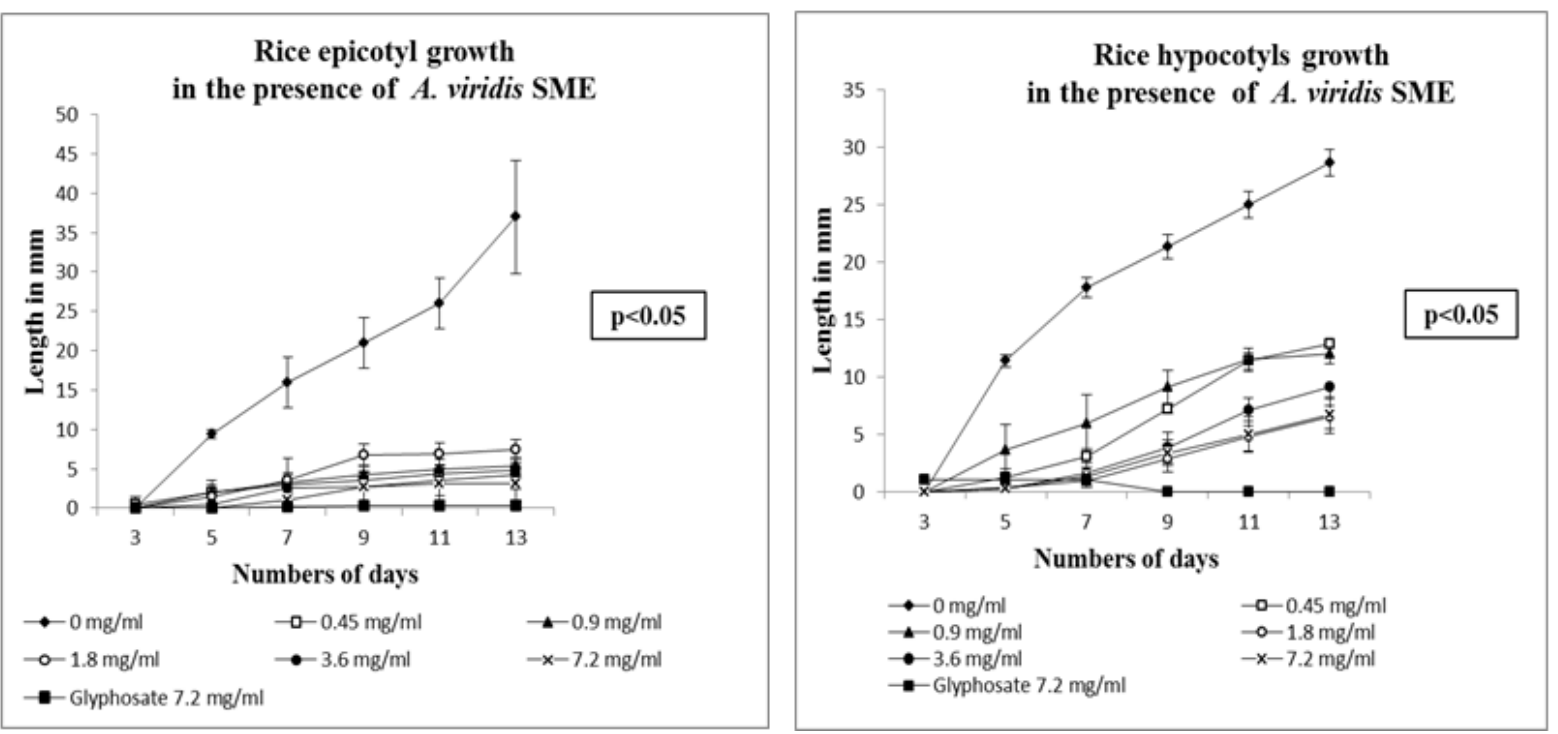

Fig. 3. Effects of A. viridis SME on rice seedling growth.
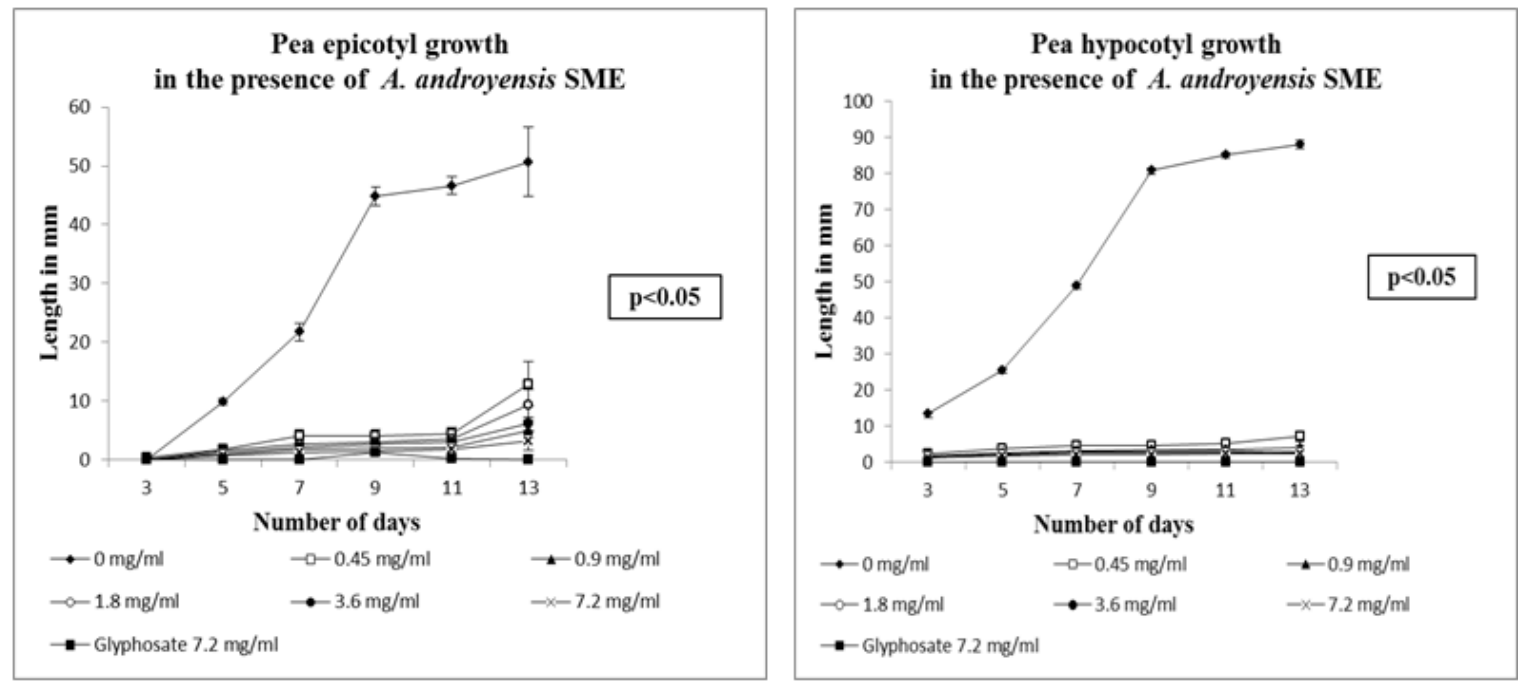

Fig. 4. Effects of A. androyensis SME on pea seedling growth. 

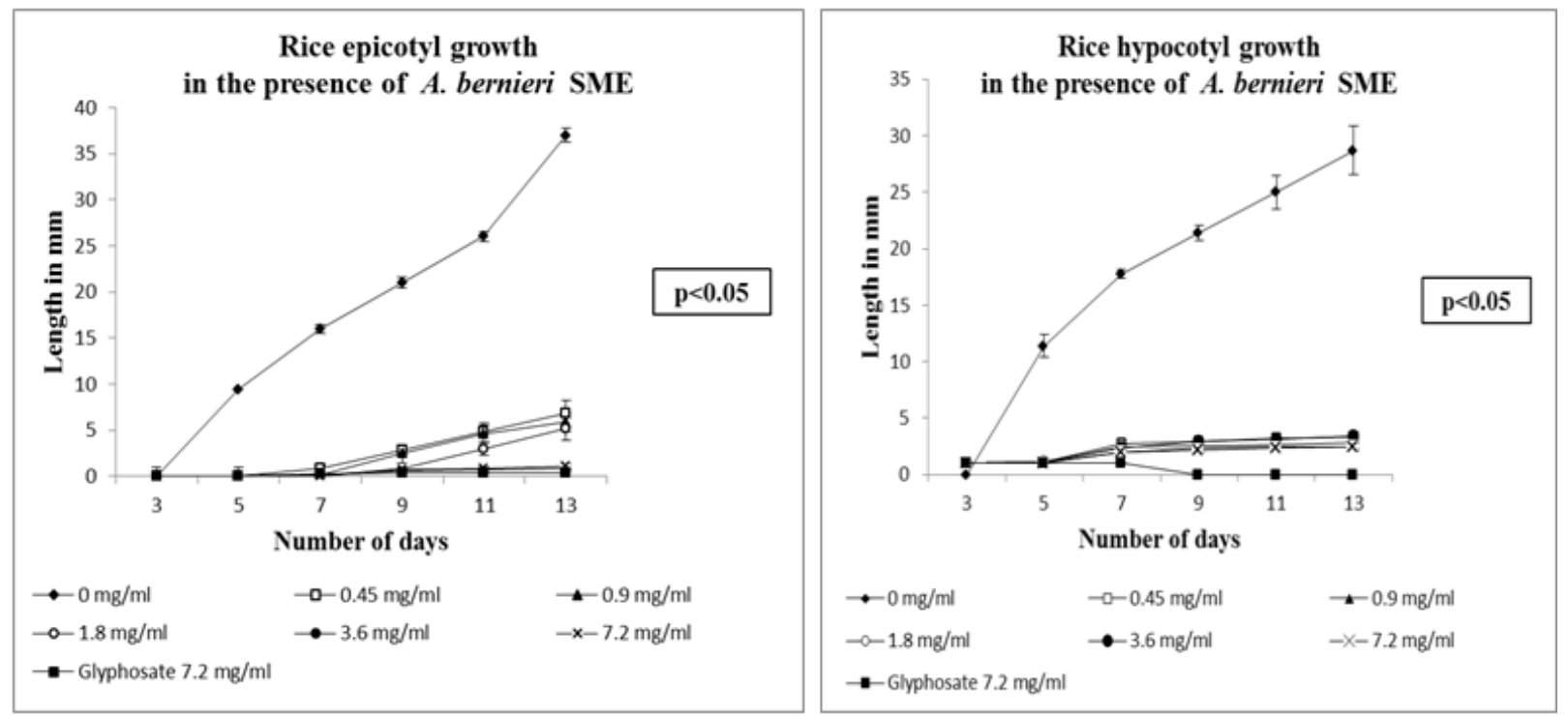

Fig. 5. Effects of A. bernieri SME on rice seedling growth.
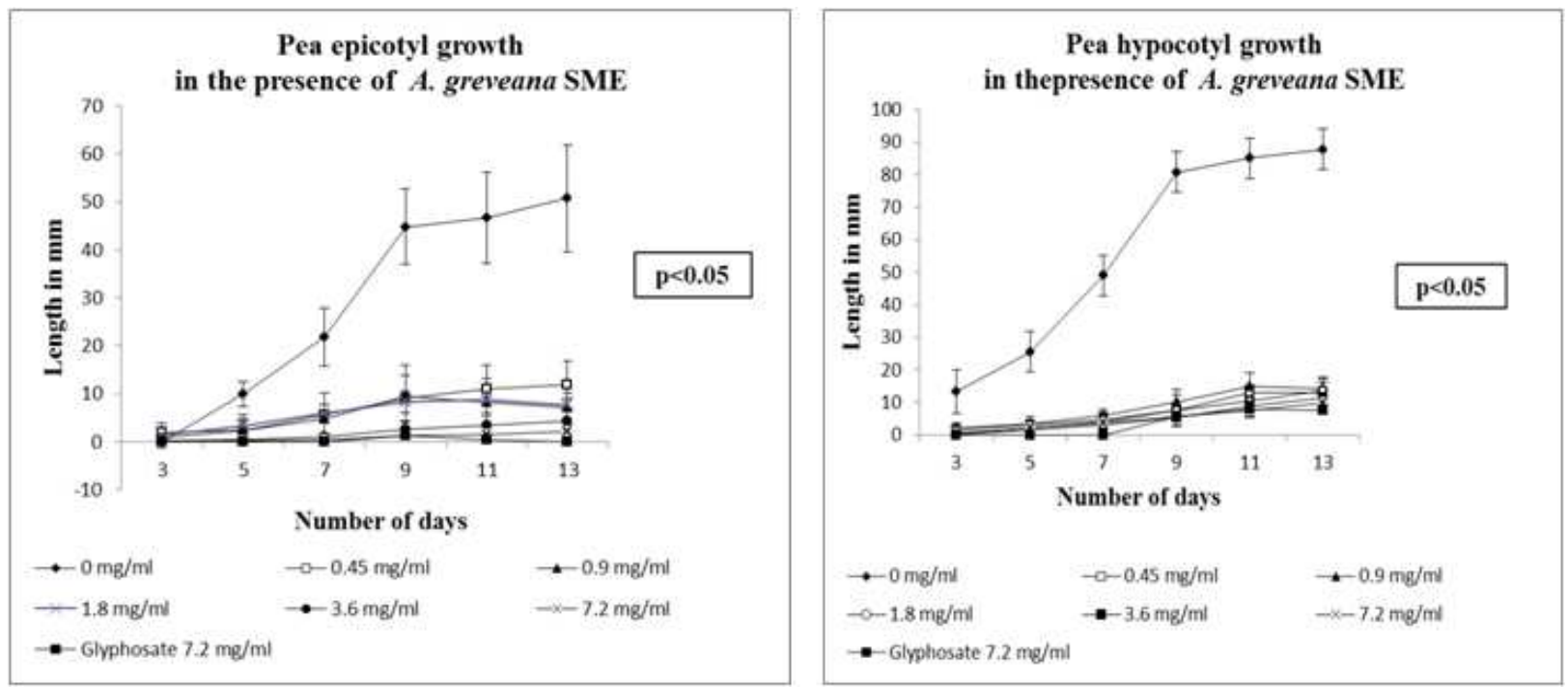

Fig 6. Effects of A. greveana SME on pea seedling.

The hypocotyl and epicotyl length was both reduced (tables 5-8 and fig. 2-6). In most cases the hypocotyl length was more affected than the epicotyl length whereas in other cases the opposite result was observed as in bean treated with $A$. androyensis SME (hypocotyl inhibited by $83.6 \%$ and epicotyl by $94.1 \%$ ) and with $A$ viridis. SME (hypocotyl inhibited by $33.2 \%$ and epicotyl by $44.4 \%$ (table 4 ).

The most pronounced inhibitory effect was observed on pea and rice treated with $A$. divaricata SME at $1 \mathrm{mg} / \mathrm{mL}$ where hypocotyl length was reduced by $99.7 \%$ and $100 \%$ respectively (table 8 and fig. 2). The inhibitory potential of $A$. androyensis SME on maize (table 5) and pea (tab. 6) was also worth pointing out: the hypocotyl and epicotyl development was indeed strongly affected with inhibition rate ranging from $71.0 \%$ to $98.6 \%$ and $91.5 \%$ to $99.3 \%$ respectively at the used concentrations $(0.45-7.2 \mathrm{mg} / \mathrm{mL})$.

At the same concentration $(7.2 \mathrm{mg} / \mathrm{mL})$ the inhibitory effect of some Albizia SME was as high as glyphosate: for example on maize (table 5) and bean (table 4) treated with $A$. divaricata SME the inhibition rate reached $100 \%$ for both hypocotyl and epicotyl.

\section{Discussion}

As far as we know, except our previous investigations [15], Albizia samans, seemed to be the only species in the Albizia genus studied on phtytotoxicity point of view [22].

The results demonstrated that Albizia SME contain some phytochemicals capable of affecting both germination and seedling growth.

The response of various test species to the same extract treatment was different. This may be due to physiological or morphological difference in them [22].

It was reported that root is higher sensitive to phytotoxic compounds than shoot [24]. Root tissue is more permeable to allelochemicals than shoot tissue [25]. By contrast, several 
Albizia SME exhibited more pronounced inhibitory effect on epicotyl than on hypocotyl.

In some cases, Albizia SME exhibited inhibition rates as high as pure glyphosate at the same concentration (7.2 $\mathrm{mg} / \mathrm{mL}$ ). Pure active principles from these extracts could be expected to be as efficient if not more so as glyphosate.

The inhibitors involved in the Albiza SME phytotoxicity might interact with basic physiological and biochemical processes. Hormonal balance, protein synthesis, photosynthesis, respiration, chlorophyll production, plant-water relations and permeability may be disturbed by allelochemicals [26, 27]. The allelochemicals might have also prevented water uptake [28] or caused an alteration in the synthesis or activation of gibberellic acid, a growth promoting hormone [29].

Stimulatory effect on seedling growth at low concentrations was considered as a common phenomenon in several plant extracts [30]. This was also observed in some Albizia SME but not in others where inhibitory effects were recorded at the same concentrations. Such result was reported about the action of a phenolic compound isolated from Carya cathayensis on the growth of different plant seedling [31]. A stimulatory effect up to $200 \%$, much higher than that exerted by regiolone, the principal component of walnut husk, on lettuce and radish growth (160\%) [32] was observed.

At the same concentration a same Albizia SME had a stimulatory effect on some test plants but an inhibitory effect on others. Moreover, the level of its stimulation or inhibition activity was variable. Those results suggested that the Albizia SME effects were selective.

Although phenolic compounds were the allelochemicals often found to be involved in seed and seedling growth inhibition [30, 34-36], they could not be responsible of the Albizia SME phytotoxicity. Indeed, according to phytochemical study on Albizia species SME, except for $A$. bernieri SME, phenolic compounds were absent [17]. Alkaloids and saponins the most frequent secondary metabolites in most of these Albizia seeds and other chemical groups such as terpenoids and heterosides might be involved in their phytotoxic activity. Other potential inhibitors of germination and seedling growth such as terpenes, glucosides, alkaloids, amino acids and sugars were reported [37-42]. Total alkaloids from seeds of the medicinal plant Peganum harmala L. were found to possess strong growth inhibitory effect on lettuce, wheat, amaranth and ryegrass [23].

Preliminary results so far obtained on weeds and invasive plants here studied were encouraging. Thus the phytotoxic compounds of Malagasy Albizia seeds could be further explored as natural herbicides and plant growth regulators. Natural products would likely be very biodegradable, thus posing less risk to the environment [23]. There have been successful examples of using natural products, including allelochemicals, as sources to develop commercial herbicides [43]; for instance, mesotrione, a synthesized analogue of leptospermone that is produced by Callistemon citrinus [44], and cinmethylin, a derivative of 1,4-cineole that is a natural phytotoxin found in the essential oils of a number of plants
[45]. More importantly, natural phytotoxins were found to act on a large number of unexploited herbicide target sites, which can be used to deal with the rapid evolving resistance to synthetic herbicides [46].

For the Albizia plants, the seed secondary metabolites may represent an efficient tool for self-defense against predation and play an important role in allelopathic interactions with other plants. There is need to examine the chemical nature of inhibitors and carry out field experiments to ascertain the ecological role of allelopathic potential of the secondary metabolites in Albizia seeds.

\section{Conclusion}

All the Albizia SMEs were found to inhibit the seed germination of vegetables, weeds and invasive plants. They also inhibited the early seedling growth of test plants and in some cases, inhibition was as high as glyphosate a widely weed-killer used in agriculture. Their phytotoxicity was likely involved in a defense process against animal predation and in allelopathic interactions with other plants and therefore their use as herbicide might be explored. On the other hand, some of them strongly stimulated the seedling growth up to $200 \%$ at low concentrations and under this condition they might also be used to promote seedling growth.

Purification of active principles from each Albizia extract and determination of their chemical nature and mode of action are the priority studies required to complete those preliminary works. They are in progress in our laboratory.

\section{Acknowledgment}

The authors are grateful to the National Tree Seed Centre (SNGF) for providing Albizia seeds and technical support.

\section{References}

[1] J. Caseley and L. Copping, Twenty-five years of increasing glyphosate use: the opportunities ahead, Pest Manag. Sci. 56 (2000) 297.

[2] D-S. Kim, J. Caseley, P. Brain, Rapide detection of propanil and fenoxaprop resistance in Escherichia coli Weed Sciences 48 (2000) 695-700.

[3] A. D. Baylis, Why glyphosate is a global herbicide: strengths, weaknesses and prospects, Pest Manag Sci 56 (2000) 299-301.

[4] [P. Neve, J. Sadler, Multiple herbicide resistance in a glyphosate-resistant rigid ryegrass (Lolium rigidum) population, Weed Science, 52 (2004) 920-928.

[5] C-H. Huangfu, X-L. Song, S. Qiang and H-J. Zhang, Response of wild Brassica juncea populations to glyphosate, Pest Manag. Sci. 63 (2007) 1133-1140.

[6] J. B. Berry, M. Gantar, M. H. Pereez, G. Berry and F. G. Noriega, Cyanobacterial toxins as allelochemicals with potential applications as algaecides, herbicides and insecticides, Mar. drugs 6 (2008) 117-146. 
[7] R. Tsao, F. E. Romanchuck, C. J. Peterson and J. R. Coats, Plant growth regulatory effect and insecticidal activity of extracts of Tree Heaven (Ailanthus altissima L.), BMC Ecology 2 (2002) 1-6.

[8] Cantrell, C.L., Dayan, F.E., Duke, S.O., Natural products as sources for new pesticides. Journal of Natural Products 75 (2012) 1231-1242.

[9] S. Arowosegbe and A. J. Afolayan, Assessment of allelopathic properties of Aloe ferox Mill. on turnip, beetroot and carrot. Biol. Res. 45 (2012) 363-368.

[10] V. L. R. Jeannoda, D. A. D. Rakoto-Ranoromalala, J. Valisolalao, E. E. Creppy and G. Dirheimer, Natural occurrence of methionine sulfoximine in the Connaraceae family, Journal of Ethnopharmacology, 14, (1985) 11-17.

[11] V. L. R. Jeannoda, J. Valisolalao, E. E. Creppy and G. Dirheimer, Identification of the toxic principle of Cnestis glabra (Connaraceae) as methionine sulfoximine, Phytochemistry 24 (1985) 854-855.

[12] L. Rakotobe, L. Mambu, A. Deville, L. Dubost, V. Jeannoda, D. Rakoto, B. Bodo, Clerodane and 19-norclerodane diterpenoids from the tubers of Dioscorea antaly, Phytochemistry 71 (2010) 1007-1013.

[13] V. Razafintsalama, M. Girardot, R. Randrianarivo, D. Rakoto, S. Sarter, T. Petit, S. Ralambonirina, A. Deville, P. Grellier, V. Jeannoda, L. Mambu, Dilobenol A-G, diprenylated dihydroflavonols from leaves of Dilobeia thouarsii. Eur. J. Chem., 87 (2013) 1936-1949.

[14] [13] D. A. D. Rakoto, C. Rajemiarimoelisoa, R. Randrianarivo, D. Ramamonjison, C. Raheriniaina, N. Raharisoa, V. Jeannoda, Antimicrobial Activity of Some Endemic Species of Albizia (Fabaceae) from Madagascar, Asian Biotechnology and Development Review, 13 (2011) 53-60.

[15] D. A. D. Rakoto, R. Randrianarivo, M. El-Yachouroutui, A. A. Arisoa, N. Raharisoa, N. Rakotondrasoa, P. Raoniharisoa, V. Jeannoda, Effects of Extracts from Albizia (Fabaceae) Endemic Species of Madagascar on Vegetable Seedling Development, J. Chem. Chem. Eng. 6 (2012) 313-322.

[16] L. Randriamampianina, A. Offroy, L. Mambu, R. Randrianarivo, D. Rakoto, V. Jeannoda, C. Djediat, S. Puiseux Dao, M. Edery, Marked Toxicity of Albizia bernieri Extracts on Embryo-larval Development in the Medaka Fish (Oryzias latipes), Toxicon 64 (2013) 29-35.

[17] H. R. Randrianarivo, A. R. Razafindrakoto, H. C. Ratsimanohatra, L. J. Randriamampianina, C. F. Rajemiarimoelisoa, L. Ramamonjisoa, D. Ramanitrahasimbola, D. A. D. Rakoto, V. L. Jeannoda, Toxic effects of seed methanolic extracts of endemic Albizia species (Fabaceae) from Madagascar on animals, Journal of life Sciences, (2014), in press.

[18] D. J. Du Puy, J. N. Labat., R. Rabevohitra, J. F. Villiers, J. Bosser, J. Moat, The Leguminosae of Madagascar Eds. Royal Waterman Botanic Garden: Kew, (2002) 750 pp.

[19] B. Lisan, Les plantes invasives à Madagascar, http://benjamin.lisan.free.fr/projetsreforestation/plantes-invasi ves-de-Madagascar.pdf.i

[20] H. Merlier and J. Montegut, Adventices tropicales, ORSTOM-GERDAT-ENSH, (1982)
[21] CIRAD, Panicum subalbidum Kunth-Poaceae -Monocotylédone, http://idao.cirad.fr/species.

[22] Noor and M. Ajmal Khan, Allelopathic potential of Albizia samans Merr. Pak. J. Bot., 26 (1) (1994) 39-147.

[23] H. Shao, X. Huang, Y. Zhang and C. Zhang, Main Alkaloids of Peganum harmala L. and their different effects on Dicot and Monocot crops, Molecules 18, (2013) 2623-2634

[24] [Su Chon, J. H. Gouttis, C. J. Nelson, Effects of light, growth media and seedling orientation on bioassays pf alfalfa autotoxicity, Agron J. 92 (2000) 715-720.

[25] N. Nishida, S. Tamotsu, N. Nagata, S. Saito, A. Sakai, Allelopathic effects of volatile monoterpenoids produced by Salvia leucophylla: Inhibition of cell proliferation and DNA synthesis in the root apical meristem of Brassica campestris seedlings, J. Chem. Ecol. 31 (2005) 1187-1203.

[26] A. S. A. Alhammadi, Allelopathic effect of Tagetes minuta L. water extracts on seeds germination and seedling root growth of Acacia asak. Ass. Univ. Bull. Environ. Res.11 (2008)17-24.

[27] A. Yamane, H. Nishimura and J. Mizutani, Allelopathy of yellow field cress (Rorripa sylvestris): Identification and characterization of phytotoxic constituents, Chem. Ecol, 18 (1992) 683-691.

[28] A. M. Tawaha, M. A. Turk Allelopathic effects of black musard (Brassica nigra) on germination and growth of wild barley (Hordeum spontanenm). J. Agron. Crop Sci. 189 (2003) 298-303.

[29] M. Olofsdotter, Rice - a step toward use of allelopathy, Agron. J. 93 (2001) 3-8.

[30] S. Abugre and S. J. Quashie-Sam, Evaluating the Allelopathic Effect of Jatropha curcas aqueous extract on germination, radicle and plumule length of crops, Int. J. Agric. Biol. 12 (2010) 769-772

[31] Li X. X., Yu M.F., Ruan X., Zhang Y.Z., Wang Q., Phytotoxicity of 4,8-Dihydroxy-1-tetralone isolated from Carya cathayensis Sarg to various plant species. Molecules. 19 (2014) 15452-15467

[32] Ciniglia, C.; Sansone, C.; Panzella, L.; Napolitano, A.; d'Ischia, M., Effects of walnut husk washing waters and their phenolic constituents on horticultural species. Environ. Sci. Pollut. Res. 19 (2012) 3299-3306.

[33] Ladhari A., Omezzine F., Dellagreca M., Zarrelli A., Zuppolini S., Haouala R. Phytotoxic activity of Cleome arabica L. and its principal discovered active compounds. South African Journal of Botany 88 (2013) 341-351.

[34] H. M. Appel, Phenolics in ecological interactions: the importance of oxidation. J. Chem. Ecol. 19, (1993) 1521-1552.

[35] L. Inderjirt, Plant phenolics in allelopathy. Bot. Rev. 62 (1996) 186-202.

[36] H. P. Singh, D. R. Batish, J. K. Pandher and R. K. Kohli, Phytotoxic effects of Parthenium hysterophorus residues on three Brassica species, Weed Biol. Manag. 5(3) (2005). 105-109.

[37] R. H. Whittaker and P. P. Feeny, Allelochemics: chemical interactions between species, Science, N. Y. 171 (1971) 757-770. 
[38] J. B. Harborne, Introduction to ecological biochemistry, Academic Press. London. (1977) 242 pp.

[39] D. R. Batisha, H. P. Singha, R. K. Kohlia, D. B. Saxenab, Kaur Shalinder, Allelopathic effects of parthenin against two weedy species, Avena fatua and Bidens pilosa, Environmental and Experimental Botany 47 (2002) 149-155.

[40] J. L. Herro and R .M. Calaway, Allelopathy and exotic plant invasion. Plant and Soil, 256 (2003) 29-39.

[41] Z. S. Siddiqui, and A. U. Zaman, Effects of systemic fungicide (benlate) on germination, seedling growth, biomass and phenolic contents of two different varieties of Zea mays. Pak. J. Bot. 36 (2004) 577-582.

[42] Z. S. Siddiqui and A. U. Zaman, Effects of Capsicum leachates on germination, seedling growth and chlorophyll accumulation in Vigna radiata L. Wilczek. Seedlings. Pak. J. Bot., 37(4) (2005) 941-947.

[43] J. R. Vyvyan, Allelochemicals as leads for new herbicides and agrochemicals, Tetrahedron, 58, (2002)1631-1646.

[44] G. Mitchell, D. W. Bartlett, T. E. Fraser, T. R. Hawkes, Holt D. C., Townson J. K., Wichert R. A., Mesotrione: A new selective herbicide for use in maize. Pest Manag. Sci. 2001, 57, 120-128.

[45] B. T. Grayson, K.S. Williams, P. A. Freehauf, R. R. Pease, W. T. Ziesel, R. L. Sereno, R. E Reinsfelder, The physical and chemical properties of the herbicide cinmethylin (SD 95481). Pestic. Sci., 21 (1987) 143-153.

[46] S. O. Duke, F. E. Dayan, J. G. Romangni, A. M. Rimando, Natural products as sources of herbicides: current status and future trends. Weed Res., 40 (2000) 99-111. 